\title{
Biocontrol of Carrot Disease-Causing Pathogens Using Essential Oils
}

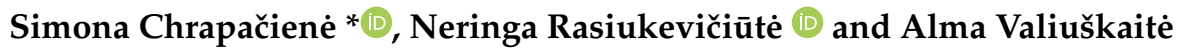

Citation: Chrapačienè, S.;

Rasiukevičiūtè, N.; Valiuškaitè, A. Biocontrol of Carrot Disease-Causing Pathogens Using Essential Oils. Plants 2021, 10, 2231. https:// doi.org/10.3390/plants10112231

Academic Editor: Walter Chitarra

Received: 15 September 2021

Accepted: 18 October 2021

Published: 20 October 2021

Publisher's Note: MDPI stays neutral with regard to jurisdictional claims in published maps and institutional affiliations.

Copyright: (c) 2021 by the authors. Licensee MDPI, Basel, Switzerland. This article is an open access article distributed under the terms and conditions of the Creative Commons Attribution (CC BY) license (https:/ / creativecommons.org/licenses/by/ $4.0 /)$.
Laboratory of Plant Protection, Lithuanian Research Centre for Agriculture and Forestry, Institute of Horticulture, Babtai, LT-54333 Kaunas, Lithuania; neringa.rasiukeviciute@lammc.lt (N.R.); alma.valiuskaite@lammc.lt (A.V.)

* Correspondence: simona.chrapaciene@lammc.lt

\begin{abstract}
Diseases caused by fungal pathogens such as Alternaria spp. damage the commercial appearance of carrots or cause foliage diseases, resulting in significant yield losses each year and are a source of pre- and postharvest rots. European commission encourages the reduction of chemical pesticides. Therefore, the potential of essential oils for alternative plant protection is increasingly discussed. Furthermore, essential oils naturally produced by aromatic plants are rich in secondary metabolites, which possess several biological activities, and their use could be a significant step in environmentally friendly food production. This study aimed to evaluate the Origanum vulgare subsp. vulgare and Origanum vulgare subsp. hirtum essential oils efficacy on Alternaria spp. growth inhibition. A Clevenger-type apparatus was used to extract the essential oils from the fresh material. The Alternaria spp. radial colony growth was evaluated under essential oils concentrations from 200 to $600 \mu \mathrm{L} \mathrm{L}^{-1}$. Each essential oil separately was mixed with a PDA medium and Alternaria spp. disk placed in the center of the Petri dishes. Plates were incubated at $25{ }^{\circ} \mathrm{C}$ in the dark and evaluated $1,2,3$, and 7 days after inoculation. The results revealed little difference between the essential oils, and the most effective concentration was $600 \mu \mathrm{L} \mathrm{L}^{-1}$ of $O$. vulgare subsp. vulgare essential oil and $400 \mu \mathrm{L} \mathrm{L}^{-1}$ of $O$. vulgare subsp. hirtum. Our findings can help to control carrot disease-causing pathogens Alternaria spp., but further research is needed.
\end{abstract}

Keywords: Alternaria spp.; oregano; essential oil; antifungal activity; plant protection

\section{Introduction}

Essential components of global agriculture systems like agrochemicals and pesticides created a vital increase in crop yields and food production over the last century [1] Nevertheless, worldwide studies have documented the pollution and consequence of agrochemical residues in soils, terrestrial and marine ecosystems [2-5]. In addition, several reports have declared that the increased number of pesticide-resistant strains of microorganisms, which demands the use of more concentrated chemicals, increases the risk of high-level toxic residues in fresh produce [6,7]. According to the Farm to Fork Strategy of the European Green Deal, there is an urgent need to reduce dependency on pesticides and antimicrobials, reduce excess fertilization, increase organic farming, and reverse biodiversity loss. The risk of using pesticides already decreased by $20 \%$ in the past five years. A further European Commission plan is to ensure the reduction of the overall use and risk of chemical pesticides by $50 \%$ by 2030 [8]. However, the rigorous regulations concerning the use and disposal of synthetic chemicals dramatically limit the possibility of perceiving future control strategies based only on pesticides. While chemical control is increasingly questioned because of its putative impact on the environment and human health, implementing alternative crop disease management solutions is imperative.

Carrot (Daucus carota L.) from the Apiaceae family is one of the popular root vegetables grown worldwide, rich in dietary carotenoids $[9,10]$. Carrot is biennial and produces a rosette of leaves on a compressed stem and a fleshy edible storage root in the first year of growth. This vegetable is also valued for its long shelf life at low temperatures. However, 
there are numerous carrot diseases responsible for significant yield losses [11,12]. Among them, Alternaria species are considered the most destructive and economically meaningful pathogens [13]. These necrotrophic fungi cause carrot Alternaria leaf blight and black rot, leading to pre- and postharvest damage. These diseases reduce carrots' nutritional value, shelf life, and their resistance to diseases and destroy their aesthetic appearance. In the past, these infections did not cause significant losses to carrot growers. Still, over the past two decades, the harmfulness of pathogens of the genus Alternaria has increased dramatically worldwide. Depending on environmental conditions, cultivation technology, variety resistance, and other factors, yield losses can reach 40-60\% [13,14].

Moreover, commercial carrot crops with weak and unhealthy foliage suffer the most because self-propelled multi-row mechanical harvesters are used with the grab belt system that catches the ground parts of the carrots and lifts them. Such harvesting requires robust, healthy foliage; otherwise, damaged leaves detach from the root, and carrots remain in the soil [14].

Alternaria fungi can produce more than 70 toxins, the most commonly studied natural contaminants in food are alternariol, alternariol monomethyl ether, and tentoxin, which play essential roles in fungal pathogenicity and food safety since some are toxic to plants and living organisms [14-16].

A wide diversity of biological control agents appear as safe and eco-friendly alternatives to pesticides to manage plant pathogens, while some even stimulate plant growth and improve soil structure at the same time [12,13]. For example, essential oils extracted from the leaves, stems, bark, and various parts of the plants contain complex mixtures of secondary metabolites, which are biologically active, endowed with antioxidant, allelopathic, bioregulatory, and antimicrobial properties. Other advantages of plant-based pesticides are their wide acceptance by consumers and potential multi-purpose uses [17-20].

Origanum vulgare L. belongs to the Lamiaceae family and is widely used as a spice and medicine. Furthermore, the potential of oregano as a protective agent in chronicdegenerative and infectious diseases was documented because of the anticancer, hepatoprotective, anti-inflammatory, antioxidant, and antimicrobial activities [21]. Therefore, it is believed that plant-derived extraction products of $O$. vulgare could be used in plant protection and prevent many pathogens' growth and development. Furthermore, as this volatile oil is natural, non-phytotoxic, and biodegradable, it can overcome problems caused by chemical pesticides.

Reports on Origanum vulgare subsp. vulgare and Origanum vulgare subsp. hirtum efficacy against plant pathogens can be found in the literature [21-26]. It was previously found that extracts obtained from both plants effectively suppressed Aspergillus niger, Aspergillus ochraceus, and Fusarium proliferatum [24]. Another study [23] also reported a good antifungal activity against Salmonella enteritidis. In addition, the essential oils of both species exhibited moderate antibacterial and antifungal activities against Sarcina lutea and Candida albicans [25]. However, there is a lack of research on the effects of O. vulgare subsp. vulgare and O. vulgare subsp. hirtum essential oils on fungi of the genus Alternaria. Therefore, the current study aimed to evaluate the O. vulgare subsp. vulgare and O. vulgare subsp. hirtum essential oils efficacy on Alternaria spp. growth inhibition.

\section{Results}

The radial colony growth rate of the pathogens Alternaria spp. during the experimental period under the different concentrations of Origanum vulgare subsp. hirtum $(\mathrm{OVH})$ essential oil (EO) is presented in Figure 1. The OVH EO at all tested concentrations suppressed the pathogen's growth compared with the control at the beginning of the experiment. The lowest radial colony growth rate was at $400 \mu \mathrm{L} \mathrm{L}^{-1} 1$ day after inoculation (DAI). The most considerable increase in colony growth was after 2 days. The concentration of $600 \mu \mathrm{L} \mathrm{L}^{-1}$ showed the most robust antifungal activity against Alternaria spp. At $200 \mu \mathrm{L} \mathrm{L}^{-1}$, the growth rate was very similar to the treatment with no EO. On the third assessment day, the EO effect on this pathogen was reduced, and mycelial growth was best controlled with a 
concentration of $400 \mu \mathrm{L} \mathrm{L}^{-1}$. This EO did not demonstrate significant suppression at 200, 400 , and $600 \mu \mathrm{L} \mathrm{L}^{-1}$ at $7 \mathrm{DAI}$; the radial colony growth rates were comparable.

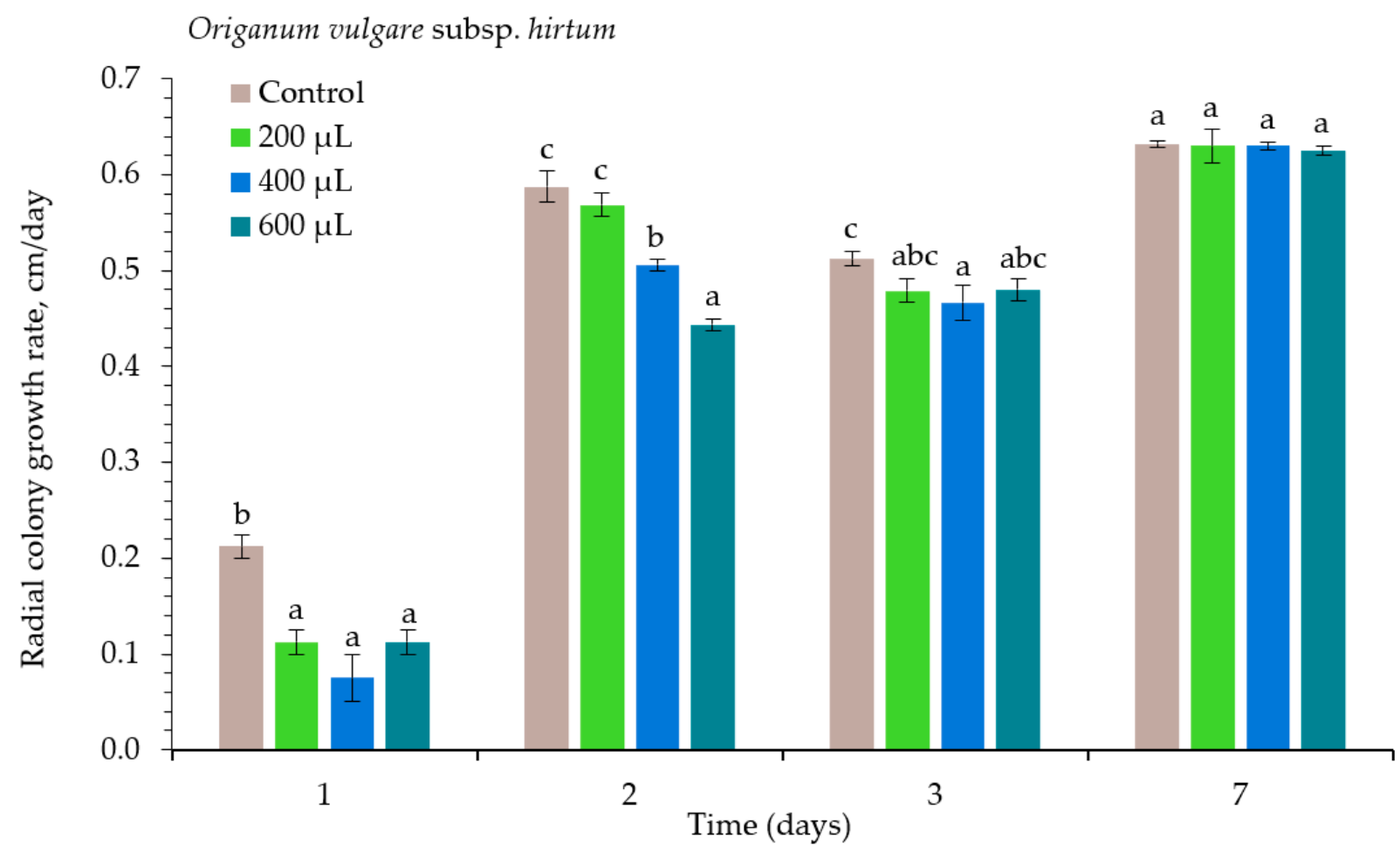

Figure 1. The radial colony growth rate of Alternaria spp. under the influence of Origanum vulgare subsp. hirtum essential oil. The same letter indicates no significant differences between treatments $(p<0.05)$.

The antifungal effect of different concentrations of $O$. vulgare subsp. vulgare (OVV) $\mathrm{EO}$ on Alternaria spp. radial colony growth rate is presented in Figure 2. Throughout the experiment, suppression of mycelial growth increased with EO concentration. Treatment with $600 \mu \mathrm{L} \mathrm{L}^{-1}$ of OVV EO showed the best antifungal activity against this pathogen and significantly differed from the control at 1, 2, 3, and 7 DAI. The radial colony growth rates at 200 and $400 \mu \mathrm{L} \mathrm{L}^{-1}$ were similar at 2,3, and $7 \mathrm{DAI}$, as no significant differences were observed.

Mycelial growth inhibition was determined according to the radial colony growth rates for different treatments (Table 1). The results demonstrate that OVH EO showed low antifungal activity on Alternaria species compared to the control at 3 and 7 DAI. By contrast, the application of OVV EO showed higher inhibition compared to the control.

The assay revealed that the investigated O. vulgare subsp. hirtum EO and O. vulgare subsp. vulgare EO concentrations of $200-600 \mu \mathrm{L} \mathrm{L}^{-1}$ have unequal potential to suppress colony growth of Alternaria spp. Higher OVV oil concentrations, like $600 \mu \mathrm{L} \mathrm{L}^{-1}$, significantly inhibited fungal growth. However, $\mathrm{OVH}$ oil suppression was inefficient: the best and consistent result was shown with $400 \mu \mathrm{L} \mathrm{L}^{-1}$. 


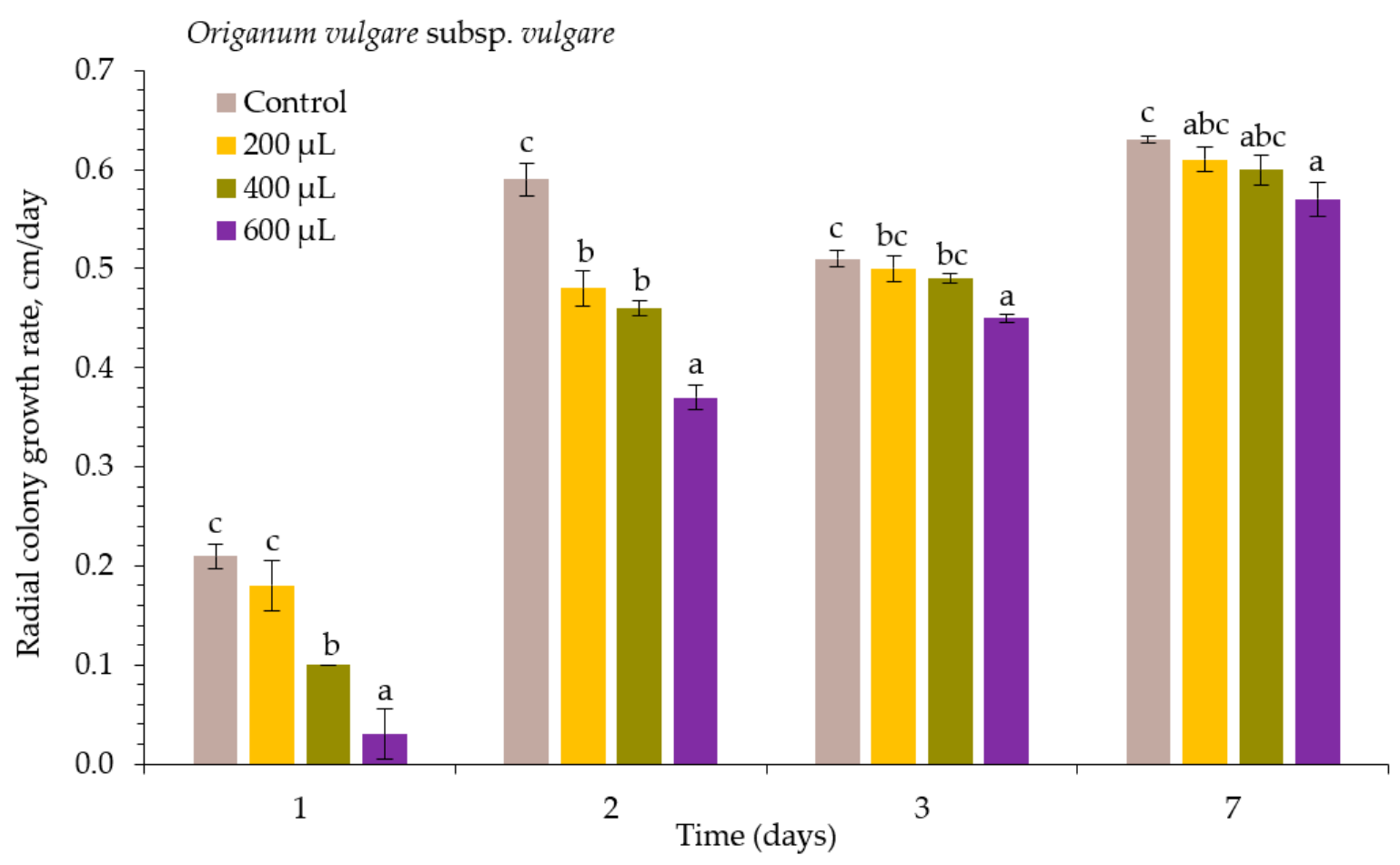

Figure 2. The radial colony growth rate of Alternaria spp. under the influence of Origanum vulgare subsp. vulgare essential oil. The same letter indicates no significant differences between treatments $(p<0.05)$.

Table 1. Mycelial growth inhibition of Alternaria spp. by different essential oils compared to the control at 1,3 , and 7 days after inoculation.

\begin{tabular}{ccccc}
\hline \multirow{2}{*}{ Essential Oil } & $\begin{array}{c}\text { Concentration } \\
\boldsymbol{\mu} \mathbf{L ~ L ~}^{-\mathbf{1}}\end{array}$ & \multicolumn{3}{c}{ Inhibition of Alternaria spp., \% } \\
\cline { 3 - 5 } & 200 & 14.29 & 3 DAI & 7 DAI \\
\hline \multirow{2}{*}{ Origanum vulgare } & 400 & 52.38 & 1.96 & 3.17 \\
subsp. vulgare & 600 & 85.71 & 3.92 & 4.76 \\
& 200 & 47.06 & 6.50 & 9.52 \\
\hline \multirow{2}{*}{ Origanum vulgare } & 400 & 64.71 & 8.94 & 0.34 \\
subsp. hirtum & 600 & 47.06 & 6.34 & 0.34 \\
& & & & 1.13 \\
\hline
\end{tabular}

\section{Discussion}

The importance of reducing the environmental pollution in the agricultural and food sectors requires searching for alternative plant protection products. This study evaluated OVV and OVH EO efficiency on Alternaria spp. Many attempts have been made to discover alternative ways of controlling Alternaria spp. and reducing the use of fungicides $[11,13,17,20,21]$. Essential oils and plant extracts are two of the most promising groups of natural compounds for the development of safer fungicidal agents. There are significant results with Thymus vulgaris L., Lavandula angustifolia Mill., Allium sativum L., Zingiber officinale Roscoe, and other EO efficacy to control the growth of these pathogens $[17,20]$.

The general antifungal activity of oregano extraction products was studied on microscopic fungi like Ryzopus stolonifer, Penicillium digitatum, Botrytis cinerea, A. ochraceus, F. proliferatum and Alternaria arborescens $[6,19,24,27,28]$. The growth of $B$. cinerea and $A$. arborescens, isolated from tomatoes, was completely inhibited by volatile vaporing at

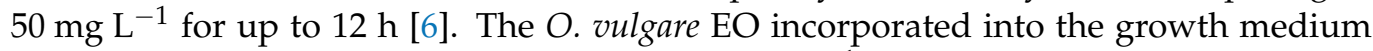
showed a fungicidal or fungistatic activity at $500 \mathrm{mg} \mathrm{L}^{-1}$. Sanit [27] also stated $100 \%$ inhibition of crude O. vulgare extract on mycelial growth and spore germination of Alternaria spp. 
at all concentrations $\left(1000-10,000 \mu \mathrm{L} \mathrm{L}^{-1}\right)$. However, the most extensive investigations have been completed against pathogenic bacteria [21]. Unfortunately, studies emphasizing the effects of different subspecies of oregano EO on Alternaria spp. were not distinguished.

In this study, both EO of OVH and OVV showed moderate ability to control fungal pathogens Alternaria spp. However, OVV expressed more potent antifungal activity than OVH EO. Other studies [25] also verified the more potent antimicrobial activity of OVV EO against seven bacterial strains: Staphylococcus aureus, Escherichia coli, S. lutea, Bacillus cereus, Pseudomonas aeroginosa, Salmonella typhimurium, Enterococcus faecalis comparing to OVH EO. However, OVH EO demonstrated promising C. albicans growth control. Contrary to our results and earlier findings [25], Askun et al. [24] reported that OVH methanol extracts had $100 \%$ inhibition against four potential mycotoxigenic fungi: A. niger, A. ochraceus. A. flavus, and F. proliferatum. Meanwhile, OVV extract demonstrated fungistatic activity against three fungi (A. niger, A. ochraceus and F. proliferatum). A. flavus was resistant to this extract in all concentrations [24]. Additionally, the OVV extract effectively suppressed microbial growth of S. enteritidis, E. coli, Listeria monocytogenes, S. aureus, A. niger and showed an excellent antifungal effect [22]. Another study [23] noted that OVH collected from different localities had vigorous antimicrobial and antifungal activities against all tested microorganisms. However, the best result was achieved on Penicillium expansum, A. flavus pathogens, and the growth of Alternaria brassicicola was moderately suppressed by this EO.

Little is known about the mechanism of action of oregano EO on Alternaria species. Although, there are reported data showing terpenoids' dose-dependent ability to inhibit mycelial growth, conidial germination, induce cell membrane dysfunction, and interfere with cell metabolism [29]. For example, thymols alone or in combination with carvacrol cause structural and functional disturbances in the cellular membrane. Thymol is a lipophilic compound that can change the cell membrane fluidity and permeability alone or with carvacrol [30]. Lambert et al. [31] highlighted that a mixture of carvacrol and thymol at proper amounts might exert the total inhibition against Pseudomonas aeruginosa and Staphylococcus aureus that is evident by oregano EO. Such inhibition is due to damage in membrane integrity, which further affects $\mathrm{pH}$ homeostasis and the equilibrium of inorganic ions [31].

In our study, the antifungal activity of EO, with main constituents of carvacrol or sabinene, $\beta$-caryophyllene, and germacrene $\mathrm{D}[26]$, was dose-dependent and manifested by inhibition of Alternaria mycelial growth. On the other hand, terpinen-4-ol and germacrene $\mathrm{D}, \beta$-caryophyllene, and spathulenol were major components in OVV produced in other countries [25]. Due to these differences in the composition of the EO, antifungal effects on pathogens may alter. For example, Abbaszadeh et al. [32] revealed that for the pathogen Alternaria alternata 5224 from Persian Type Culture Collection (PTCC), the minimum inhibitory concentrations of synthetic carvacrol $350 \mu \mathrm{L} \mathrm{mL}^{-1}$ or thymol $400 \mu \mathrm{L} \mathrm{mL}^{-1}$ are needed.

This research gives possible directions for further studies evaluating the antifungal mechanism of EO. It is indicated that the advantage of natural products from plants is their multicomponent composition providing a lower possibility for the pathogen to develop resistance quickly. Based on the results in our study, the O. vulgare subsp. vulgare plants can be considered a potential source of alternative products to the pesticides currently used to prevent fungal decay in fresh products and improve food safety.

\section{Materials and Methods}

\subsection{Fungal Material}

The Alternaria spp. isolates used in the experiments were isolated from rotten carrot roots. The carrot root fragments were surface-sterilized for $3 \mathrm{~min}$ in $70 \%$ ethanol, rinsed five times with sterile distilled water, placed on PDA (potato dextrose agar) (Liofilchem, Teramo, Italy), and incubated at $25^{\circ} \mathrm{C}$. Pathogens obtained from infected carrots were identified using $10 \times$ and $40 \times$ microscope magnification (Nikon Eclipse 80i, Melville, New York, NY, USA), evaluating their sporangiophores, sporangia, hyphae, conidiophores, conidia, colony 
texture, and growth pattern [33] and then transferring fungal mycelium onto a new PDA plate for purification to a single-spore. Isolates were incubated at $25 \pm 2{ }^{\circ} \mathrm{C}$ in the dark for 7 days and kept at $4{ }^{\circ} \mathrm{C}$ until the beginning of the experiment.

\subsection{Essential Oils Extraction}

Clevenger-type (Glassco, Ind) hydro-distillation was used for the extraction of EO from local fresh material [26,34,35]. Greek oregano (O. vulgare subsp. hirtum (Link) Ietsw), and oregano (O. vulgare subsp. vulgare L.) used for essential oils extraction were grown at Lithuanian Research Centre for Agriculture and Forestry (LAMMC) Institute of Horticulture (IH) experimental fields. The composition of the volatile compounds responsible for antifungal activities of each essential oil was determined previously using gas chromatography/mass spectrometry [26]. The main component of the O. vulgare subsp. hirtum was carvacrol, $O$. vulgare subsp. vulgare - sabinene, $\beta$-caryophyllene, and germacrene $\mathrm{D}$ [26].

\subsection{Evaluation of Essential Oils Efficiency}

The research was carried out at the Laboratory of Plant Protection LAMMC, IH. The radial growth technique was used to evaluate the EO efficiency on Alternaria spp. in vitro $[18,36,37]$. Appropriate volumes of each $\mathrm{EO}$ of OVH and OVV were added to PDA medium immediately before it was poured into the Petri dishes at $40-45^{\circ} \mathrm{C}$ to obtain a series of concentrations $\left(200,400\right.$, and $\left.600 \mu \mathrm{L} \mathrm{L}^{-1}\right)$. Four repetitions with four replications were carried out [38]. Under aseptic conditions, $5 \mathrm{~mm}$ mycelium plugs (upside down) of single spore 7-day old fungus on PDA plates isolated from carrots were placed in the center of a sterile Petri dish containing PDA and different EO concentrations $[18,36,37]$. The control treatments were without EO.

Plates were incubated at $25 \pm 2{ }^{\circ} \mathrm{C}$ in the dark, and the diameter of colony growth $(\mathrm{cm})$ was measured in two directions (transverse and longitudinal) after 1, 2, 3, and 7 days of incubation (DAI) (Figure 3).

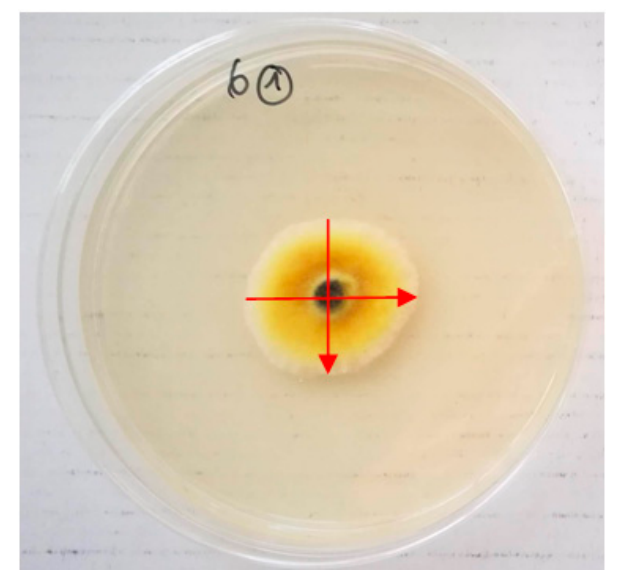

Figure 3. The measurement of the diameter of Alternaria spp. mycelium growth.

The mean of colony growth diameters $(\mathrm{cm})$ used for radial colony growth rate (cm/day) calculations [39]:

$$
C r=\frac{r}{t}
$$

$\mathrm{Cr}$-radial colony growth rate, $\mathrm{cm} /$ day; $r$-mean of colony diameters, $\mathrm{cm}$; $t$ - growth duration, days.

Radial colony growth rates were used for mycelial growth inhibition calculations using the formula by Šernaite et al. [40] with some modifications:

$$
\text { mycelial growth inhibition }(\%)=\frac{(r r c-r r t)}{r r c} \times 100,
$$


$r r c$-radial colony growth rate of the control ( $\mathrm{cm} /$ day); $r r t$-radial colony growth rate of the treated samples (cm/day).

\subsection{Statistical Analysis}

All analyses consisted of four repetitions with four replications. Data were statistically handled by one-way analysis of variance (ANOVA) and Duncan's multiple range test $(p<0.05)$ was used for the comparison of obtained means. Other calculations were completed using Microsoft Excel.

Author Contributions: Conceptualization, N.R. and A.V.; methodology, S.C., N.R. and A.V.; software, S.C.; validation, N.R.; formal analysis, S.C.; investigation, S.C.; resources, N.R.; data curation, S.C.; writing—original draft preparation, S.C.; writing—review and editing, S.C., N.R. and A.V.; visualization, S.C.; supervision, N.R. and A.V. All authors have read and agreed to the published version of the manuscript.

Funding: This research received no external funding.

Institutional Review Board Statement: Not applicable.

Informed Consent Statement: Not applicable.

Conflicts of Interest: The authors declare no conflict of interest.

\section{References}

1. Carvalho, F.P. Pesticides, environment, and food safety. Food Energy Secur. 2017, 6, 48-60. [CrossRef]

2. Solaimalai, A.; Ramesh, R.T.; Baskar, M. Pesticides and environment. In Environmental Contamination and Bioreclamation; APH Publishing Corporation: New Delhi, India, 2004; pp. 345-382, ISBN 9788176485876.

3. Rathore, H.S.; Nollet, L.M. (Eds.) Pesticides: Evaluation of Environmental Pollution; CRC Press: Boca Raton, FL, USA, 2012; p. 659, ISBN 9780367865191.

4. Mahmood, I.; Imadi, S.R.; Shazadi, K.; Gul, A.; Hakeem, K.R. Effects of pesticides on environment. In Plant, Soil and Microbes; Springer: Cham, Switzerland, 2016; pp. 253-269.

5. Rajmohan, K.S.; Chandrasekaran, R.; Varjani, S. A Review on occurrence of pesticides in environment and current technologies for their remediation and management. Indian J. Microbiol. 2020, 60, 125-138. [CrossRef]

6. Antunes, M.D.C.; Cavaco, A.M. The use of essential oils for postharvest decay control. A review. Flavour Fragr. J. 2010, 25, 351-366. [CrossRef]

7. Ricke, S.C.; Kundinger, M.M.; Miller, D.R.; Keeton, J.T. Alternatives to antibiotics: Chemical and physical antimicrobial interventions and foodborne pathogen response. Poult. Sci. 2005, 84, 667-675. [CrossRef] [PubMed]

8. European Commission. Farm to Fork Strategy: For a Fair, Healthy and Environmentally-Friendly Food System. DG SANTE/Unit 'Food Information and Composition, Food Waste'. 2020. Available online: https:/ /ec.europa.eu/food/sites/food/files/safety/ docs/f2f_action-plan_2020_strategy-info_en.pdf (accessed on 4 March 2021).

9. Klein, C.S.; Rodriguez-Concepcion, M. Carotenoids in carrot. In Pigments in Fruits and Vegetables; Chen, C., Ed.; Springer: New York, NY, USA, 2015; pp. 217-228. [CrossRef]

10. Sharma, K.D.; Karki, S.; Thakur, N.S.; Attri, S. Chemical composition, functional properties and processing of carrot-A review. J. Food Sci. Technol. 2012, 49, 22-32. [CrossRef]

11. Davis, R.M.; Nu, J. Integrated approaches for carrot pests and diseases management. In General Concepts in Integrated Pest and Disease Management; Ciancio, A., Mukerji, K.G., Eds.; Springer: Dordrecht, The Netherlands, 2007; pp. 149-188.

12. Que, F.; Hou, X.L.; Wang, G.L.; Xu, Z.S.; Tan, G.F.; Li, T.; Xiong, A.S. Advances in research on the carrot, an important root vegetable in the Apiaceae family. Hortic. Res. 2019, 6, 69. [CrossRef]

13. Le Clerc, V.; Briard, M. Carrot disease management. In Carrots and Related Apiaceae Crops, 2nd ed.; Geoffriau, E., Simon, P., Eds.; CABI Publishing: Wallingford, UK, 2020; Volume 33, pp. 115-129.

14. Farrar, J.J.; Pryor, B.M.; Davis, R.M. Alternaria diseases of carrot. Plant Dis. 2004, 88, 776-784. [CrossRef] [PubMed]

15. Escriva, L.; Oueslati, S.; Font, G.; Manyes, L. Alternaria mycotoxins in food and feed: An overview. J. Food Qual. 2017, 2017, 20. [CrossRef]

16. Leyte-Lugo, M.; Richomme, P.; Poupard, P.; Peria-Rodriguez, L.M. Identification and Quantification of a Phytotoxic Metabolite from Alternaria dauci. Molecules 2020, 25, 4003. [CrossRef] [PubMed]

17. Lukošiūtè, S.; Šernaitè, L.; Morkeliūnè, A.; Rasiukevičiūtè, N.; Valiuškaitè, A. The effect of Lamiaceae plants essential oils on fungal plant pathogens in vitro. Agron. Res. 2020, 18, 2761-2769. [CrossRef]

18. Šernaitè, L.; Rasiukevičiūtè, N.; Valiuškaitè, A. The extracts of cinnamon and clove as potential biofungicides against strawberry grey mould. Plants 2020, 9, 613. [CrossRef] [PubMed] 
19. Sil, A.; Pramanik, K.; Samantaray, P.; Firoz, M.; Yaday, V. Essential oils: A boon towards eco-friendly management of phytopathogenic fungi. J. Entomol. Zool. Stud 2020, 8, 1884-1891.

20. Mugao, L.G.; Muturi, P.W.; Gichimu, B.M.; Njoroge, E.K. In Vitro Control of Phytophthora infestans and Alternaria solani Using Crude Extracts and Essential Oils from Selected Plants. Int. J. Agron. 2020, 2020, 8845692. [CrossRef]

21. Pezzani, R.; Vitalini, S.; Iriti, M. Bioactivities of Origanum vulgare L.: An update. Phytochem. Rev. 2017, 16, 1253-1268. [CrossRef]

22. Oniga, I.; Puscas, C.; Silaghi-Dumitrescu, R.; Olah, N.K.; Sevastre, B.; Marica, R.; Hanganu, D. Origanum vulgare ssp. vulgare: Chemical composition and biological studies. Molecules 2018, 23, 2077. [CrossRef]

23. Esen, G.; Azaz, A.D.; Kurkcuoglu, M.; Baser, K.H.C.; Tinmaz, A. Essential oil and antimicrobial activity of wild and cultivated Origanum vulgare L. subsp. hirtum (Link) letswaart from the Marmara region, Turkey. Flavour Fragr. J. 2007, 22, 371-376. [CrossRef]

24. Askun, T.; Tumen, G.; Satil, F.; Kilic, T. Effects of some Lamiaceae species methanol extracts on potential mycotoxin producer fungi. Pharm. Biol. 2008, 46, 688-694. [CrossRef]

25. Sarikurkcu, C.; Zengin, G.; Oskay, M.; Uysal, S.; Ceylan, R.; Aktumsek, A. Composition, antioxidant, antimicrobial and enzyme inhibition activities of two Origanum vulgare subspecies (subsp. vulgare and subsp. hirtum) essential oils. Ind. Crop. Prod. 2015, 70, 178-184. [CrossRef]

26. Baranauskienė, R.; Venskutonis, P.R.; Dambrauskienè, E.; Viškelis, P. Harvesting time influences the yield and oil composition of Origanum vulgare L. ssp. vulgare and ssp. hirtum. Ind. Crop. Prod. 2013, 49, 43-51. [CrossRef]

27. Sanit, S. Antifungal activity of selected medicinal plants against Alternaria species: The pathogen of dirty panicle disease in rice. J. Med. Plants Res. 2016, 10, 195-201. [CrossRef]

28. Plotto, A.; Roberts, D.D.; Roberts, R.G. Evaluation of plant essential oils as natural postharvest disease control of tomato (Lycopersicon esculentum). In Proceedings of the XXVI International Horticultural Congress: Issues and Advances in Postharvest Horticulture, Toronto, ON, Canada, 11-17 August 2002; pp. 737-745. [CrossRef]

29. Scariot, F.J.; Foresti, L.; Delamare, A.P.L.; Echeverrigaray, A.S. Activity of monoterpenoids on the in vitro growth of two Colletotrichum species and the mode of action on C. acutatum. Pestic. Biochem. Physiol. 2020, 170, 104698. [CrossRef] [PubMed]

30. Ghalem, B.R.; Talia, B.; Omar, H. Antifungal Activities of Five Commercial Extracts against Alternaria alternate. J. Biotechnol. Res. 2020, 6, 98-103. [CrossRef]

31. Lambert, R.J.W.; Skandamis, P.N.; Coote, P.J.; Nychas, G.J. A study of the minimum inhibitory concentration and mode of action of oregano essential oil, thymol and carvacrol. J. Appl. Microbiol. 2001, 91, 453-462. [CrossRef]

32. Abbaszadeh, S.; Sharifzadeh, A.; Shokri, H.; Khosravi, A.R.; Abbaszadeh, A. Antifungal efficacy of thymol, carvacrol, eugenol and menthol as alternative agents to control the growth of food-relevant fungi. J. Mycol. Med. 2014, 24, e51-e56. [CrossRef] [PubMed]

33. Simmons, E.G. Alternaria: An Identification Manual; ASM Press: Washington, DC, USA, 2007; 775p, ISBN $978-9070351687$.

34. AOAC. Volatile oil in spices. In Official Methods of Analysis, 15th ed.; Helrich, K., Ed.; Association of Official Analytical Chemists: Washington, DC, USA, 1990; Volume 1.

35. Morkeliūnè, A.; Rasiukevičiūtè, N.; Valiuškaitè, A. Pathogenicity of Colletotrichum acutatum to different strawberry cultivars and anthracnose control with essential oils. Zemdirb. Agric. 2021, 10, 173-180. [CrossRef]

36. Marei, G.I.K.; Rasoul, M.A.A.; Abdelgaleil, S.A. Comparative antifungal activities and biochemical effects of monoterpenes on plant pathogenic fungi. Pestic. Biochem. Physiol. 2012, 103, 56-61. [CrossRef]

37. Feng, W.; Zheng, X. Essential oils to control Alternaria alternata in vitro and in vivo. Food Control 2007, 18, 1126-1130. [CrossRef]

38. Raudonius, S. Moksliniu Tyrimu Planavimas Ir Analizé: Mokomoji Knyga; Akademija, IDP Solutions: Kaunas, Lithuania, 2008; 139p, ISBN 9789955865186.

39. Malama, A.A.; Mironova, S.N.; Filimonova, T.V.; Moiseev, Y.V.; Gumargalieva, K.Z. The effect of temperature on growth of mycelial fungi colonies. Microbiology 1987, 54, 994-997.

40. Šernaitè, L.; Rasiukevičiūtè, N.; Valiuškaitè, A. Application of plant extracts to control postharvest gray mold and susceptibility of apple fruits to B. cinerea from different plant hosts. Foods 2020, 9, 1430. [CrossRef] [PubMed] 